Macmillan Building and Surveying Series

Series Editor: Ivor H. Seeley

Emeritus Professor, Nottingham Trent University

Advanced Building Measurement, second edition Ivor $\mathrm{H}$. Seeley

Advanced Valuation Diane Butler and David Richmond

An Introduction to Building Services Christopher A. Howard

Applied Valuation Diane Butler

Asset Valuation Michael Rayner

Building Economics, third edition Ivor $\mathrm{H}$. Seeley

Building Maintenance, second edition Ivor $\mathrm{H}$. Seeley

Building Maintenance Technology Lee How Son and George C. S. Yuen

Building Procurement Alan E. Turner

Building Quantities Explained, fourth edition Ivor H. Seeley

Building Surveys, Reports and Dilapidations Ivor H. Seeley

Building Technology, fourth edition Ivor $\mathrm{H}$. Seeley

Civil Engineering Contract Administration and Control Ivor $\mathrm{H}$. Seeley

Civil Engineering Quantities, fifth edition Ivor H. Seeley

Civil Engineering Specification, second edition Ivor $\mathrm{H}$. Seeley

Computers and Quantity Surveyors A. J. Smith

Construction Contract Claims Reg Thomas

Contract Planning and Contractual Procedures, third edition B. Cooke

Contract Planning Case Studies B. Cooke

Design-Build Explained D. E. L. Janssens

Development Site Evaluation N. P. Taylor

Environmental Science in Building, third edition R. McMullan

Greener Buildings - Environmental Impact of Property

Stuart Johnson (Editor)

Housing Associations Helen Cope

Housing Management - Changing Practice Christine Davies (Editor)

Information and Technology Applications in Commercial

Property Rosemary Feenan and Tim Dixon (Editors)

Introduction to Valuation D. Richmond

Marketing and Property People Owen Bevan

Principles of Property Investment and Pricing W. D. Fraser

Property Valuation Techniques David Isaac and Terry Steley

Public Works Engineering Ivor H. Seeley

Quality Assurance in Building Alan Griffith

Quantity Surveying Practice Ivor H. Seeley

Recreation Planning and Development Neil Ravenscroft

Small Building Works Management Alan Griffith

Structural Detailing, second edition P. Newton

Urban Land Economics and Public Policy, fourth edition

P. N. Balchin, J. L. Kieve and G. H. Bull

Urban Renewal - Theory and Practice Chris Couch

1980 JCT Standard Form of Building Contract, second edition R.F. Fellows 


\section{Series Standing Order}

If you would like to receive future titles in this series as they are published, you can make use of our standing order facility. To place a standing order please contact your bookseller or, in case of difficulty, write to us at the address below with your name and address and the name of the series. Please state with which title you wish to begin your starıding order. (If you live outside the United Kingdom we may not have the rights for your area, in which case we will forward your order to the publisher concerned.)

Customer Services Department, Macmillan Distribution Ltd Houndmills, Basingstoke, Hampshire, RG21 2XS, England. 


\title{
Greener Buildings \\ Environmental impact \\ of property
}

Stuart Johnson

with contributions from

\author{
Brian Carter \\ Colin Ferguson \\ Jagjit Singh \\ Edward Sutherland \\ Andrew Wilkes
}


Selection and editorial matter (C) Stuart Johnson 1993

Individual chapters (C) Brian Carter, Colin Ferguson, Stuart Johnson, Jagjit Singh, Edward Sutherland, Andrew Wilkes 1993

Cover illustration by Phil Radmall

All rights reserved. No reproduction, copy or transmission of this publication may be made without written permission.

No paragraph of this publication may be reproduced, copied or transmitted save with written permission or in accordance with the provisions of the Copyright, Designs and Patents Act 1988, or under the terms of any licence permitting limited copying issued by the Copyright Licensing Agency, 90 Tottenham Court Road, London W1P 9HE.

Any person who does any unauthorised act in relation to this publication may be liable to criminal prosecution and civil claims for damages.

First published 1993 by THE MACMILLAN PRESS LTD Houndmills, Basingstoke, Hampshire RG21 2XS and London Companies and representatives throughout the world

ISBN 978-0-333-57454-6 ISBN 978-1-349-22752-5 (eBook) DOI 10.1007/978-1-349-22752-5

A catalogue record for this book is available from the British Library. 


\section{Contents}

Foreword

ix

1 Introduction

Stuart Johnson 1

$\begin{array}{lll}1.1 & \text { Aims of the book } & 1\end{array}$

1.2 Structure of the book 2

1.3 Using the book 4

1.4 Notes on contributors 5

2 Environmental Issues

$\begin{array}{ll}\text { Stuart Johnson } & 8\end{array}$

$\begin{array}{lll}2.1 & \text { Introduction } & 8\end{array}$

2.2 Ozone depletion 9

2.3 Ozone depletion and buildings 10

$\begin{array}{lll}2.4 & \text { Global warming } & 12\end{array}$

2.5 Global warming and buildings 14

$\begin{array}{lll}2.6 & \text { Acid rain } & 15\end{array}$

2.7 Acid rain and buildings $\quad 16$

2.8 Neighbourhood and internal environment issues $\quad 16$

$\begin{array}{lll}2.9 & \text { Summary } & 17\end{array}$

3 Site Hazards

Colin Ferguson $\quad 20$

$\begin{array}{ll}3.1 & \text { Introduction }\end{array}$

3.2 Potentially contaminated land 20

$\begin{array}{lll}3.3 & \text { Landfill gas } & 26\end{array}$

3.4 Indoor radon and lung cancer 30

$\begin{array}{lll}3.5 & \text { Overhead power lines } & 37\end{array}$

$\begin{array}{lll}3.6 & \text { Summary } & 39\end{array}$ 
vi Contents

4 Architecture and Landscape Brian Carter

4.1 Introduction 45

4.2 Site planning $\quad 45$

4.3 Orientation 46

4.4 The characteristics of materials 47

4.5 The building envelope 49

4.6 Building systems 53

4.7 The design of the skin of the building 56

4.8 Acoustics 59

4.9 Performance 61

4.10 Summary 63

5 Energy Efficiency

Stuart Johnson and Andrew Wilkes $\quad 67$

$\begin{array}{lll}5.1 & \text { Introduction } & 67\end{array}$

$\begin{array}{lll}5.2 & \text { Benefits } & 68\end{array}$

5.3 Thermal insulation $\quad 69$

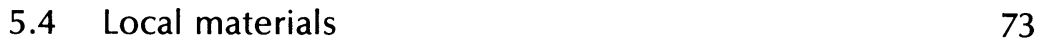

5.5 'Hidden' energy costs $\quad 74$

5.6 Design life of buildings $\quad 74$

5.7 Out-of-town schemes $\quad 75$

5.8 Energy savings in building systems and services $\quad 75$

5.9 Environmental moderating systems 77

$\begin{array}{ll}5.10 \text { A holistic approach } & 79\end{array}$

5.11 Buildings in equilibrium $\quad 81$

5.12 Life cycle costing $\quad 82$

5.13 Summary $\quad 85$

6 Building Materials

$\begin{array}{lr}\text { Stuart Johnson } & 89\end{array}$

6.1 Introduction $\quad 89$

6.2 Tropical hardwoods $\quad 90$

6.3 Chlorofluorocarbons $\quad 92$

6.4 Asbestos 93

6.5 Paints 94

6.6 Timber treatments $\quad 97$

6.7 Formaldehyde 98

6.8 Recycled materials $\quad 99$

6.9 Summary 100 
7 Engineering Services

Andrew Wilkes

104

7.1 Introduction 104

7.2 Environmental aspects of the building 105

7.3 Environmental performance 106

$\begin{array}{ll}7.4 & \text { Control of personal environments } \\ 709\end{array}$

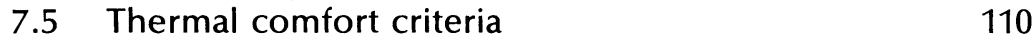

7.6 Ventilation and indoor air quality 111

7.7 Heating/ventilating/air-conditioning (HVAC) systems

7.8 Summary

8 Building Biology and Health Jagjit Singh

$\begin{array}{lll}8.1 & \text { Introduction } & 122\end{array}$

8.2 Building environments 123

8.3 Biological decay 125

8.4 Biological health hazards 136

8.5 Environmental assessment 138

8.6 Environmental control 139

8.7 Summary 140

9 Environmental Law

T Edward Sutherland $\quad 144$

9.1 Introduction 144

$\begin{array}{lll}9.2 & \text { The planning stage } & 145\end{array}$

9.3 Contaminated land 148

9.4 Construction 150

9.5 Occupied buildings 156

9.6 Demolition 157

9.7 Future developments 157

$\begin{array}{lll}9.8 & \text { Summary } & 158\end{array}$

10 Environmental Assessment

Stuart Johnson $\quad 160$

10.1 Introduction 160

10.2 BREEAM systems 161

10.3 Environmental surveys 165

10.4 Environmental impact assessments 167

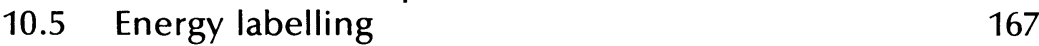

10.6 Product labelling 169

$\begin{array}{lll}10.7 & \text { Summary } & 169\end{array}$ 
viii Contents

11 Conclusions

Stuart Johnson 172

$\begin{array}{lll}11.1 & 172\end{array}$

$\begin{array}{ll}11.2 & \text { Environmental issues } \\ 11.3\end{array}$

$\begin{array}{lll}11.3 & \text { Site hazards } & 174\end{array}$

11.4 Architecture and landscape 175

$\begin{array}{lll}11.5 & 175\end{array}$

$\begin{array}{lll}11.6 & \text { Building materials } & 177\end{array}$

$\begin{array}{lll}11.7 & \text { Engineering services } & 178\end{array}$

$\begin{array}{lll}11.8 & \text { Building biology and health } & 179\end{array}$

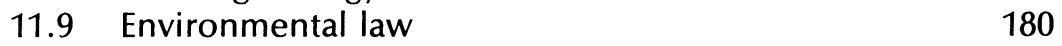

$\begin{array}{ll}11.10 \text { Environmental assessment } & 180\end{array}$

$\begin{array}{ll}11.11 \text { Overall conclusions } & 181\end{array}$

$\begin{array}{lr}\text { Index } & 183\end{array}$ 


\section{Foreword}

Heightened concern about the threat of environmental catastrophe has coincided with a downturn in the fortunes of those involved in the property market and the construction industry. There is no doubt that the present over-supply in the market is enabling occupiers to exercise their preferences by choosing the buildings that are both environmentally friendly and cheaper to run. Stuart Johnson's book is therefore not only valuable, pulling together the many environmental threads that relate to property and construction, but timely.

The agents of change are often described as the carrot and the stick but, in its ability to change course, the construction industry is more like a super-tanker than a donkey; its enormous size will make it slow to change direction even when the helm is hard over. Many believe that we will not see environmental concerns leading to action unless a legislative stick is applied to the construction industry. Statutory regulation is important but at the moment it tends to apply only to new buildings. On the other hand, information and a will to take action can affect choices in respect of both new and existing buildings. I hope that this book will provide those who feel like nibbling at the carrot of a better environment with the information they need.

It is a similar wish that has motivated The Royal Institution of Chartered Surveyors to take a keen interest in the subject of the environment by exposing members to issues of current concern and by talking to government on environmental issues affecting property and construction. The aim is to raise interest in the subject and point the direction in which the property profession can meet existing and expected demand for practical and unbiased advice.

There has been much research into the way in which buildings affect our environment. This book lists many of the current references. In bringing together contributions from a wide variety of experts it is my hope that it will enable enlightened self-interest to grow among property professionals. 
This book will help those who wish to respond to market requirements, develop their understanding of environmental issues and adapt their services to provide us with, and help us occupy, greener buildings.

Ted Watts

President, The Royal Institution of Chartered Surveyors, 1991-2 and Chairman, Watts \& Partners 